\title{
The Economics of Healthcare Systems in the Period of Global Financial Crisis - A Comparative Analysis
}

\author{
Nevena Stancheva \\ University of Economics - Varna \\ Department of International Economic Relations
}

\begin{abstract}
In this paper we discuss the connection between the global financial crisis and the need of healthcare systems reforms in the developed countries. We provide descriptive comparative analysis on health care problems in the EU and in USA. The paper focuses upon attempts to reorganize existing healthcare systems in order to make them more effective and cost-efficient in the time of financial crisis.
\end{abstract}

Keywords: healthcare systems reforms, globalization, financial crisis

\section{Резюме:}

В статията се изследва връзката между световната финансова криза и необходимостта от реформи в системата на здравеопазване в развитите страни. Представен е анализ на основните проблеми, възникнали в ЕС и САЩ, както и на решенията за реорганизация на здравеопазването, с цел да се повиши ефективността и да се намалят разходите.

\section{Introduction}

The process of economic globalization has brought a massive change in the political and the industrial systems of all countries across the globe and the healthcare systems are subjects of this process as well. In the 1990s financial globalization and financial stability gave rise to a marketoriented system in place of politically dominated system. But, now in the time of financial crisis, the national income is expected to drop significantly and the revenues in the healthcare system will decrease for most of the developed countries. Economic recession makes the task of defending health budgets more difficult. In countries affected by economic recession, sectors that generate employment will seek additional funding. Respectively the healthcare sector could be drop behind. According to World Health Organization report [1] some countries are at particular risk. These include developed countries that have required emergency assistance from the International Monetary Fund, where spending restrictions may be imposed during loan repayment.

\section{Discussion}

Most industrialized countries have established hybrid systems in which the public sector, which has the greater share of responsibility, works alongside the private sector, both in the funding of healthcare and in the delivery of hospital care. None of the EU countries provides a wholly public sector service and, in fact, the trend has been towards a decrease in the state's role in service provision, for example in the United Kingdom and Italy. In the 
EU dissatisfaction with the methods of finance and administration of healthcare has emerged in all of the Member States. [2] The common problems, albeit to different degrees, are deficiency of systems to cope with changing disease patterns, to provide equitable access to services, maintain control over costs, to utilise healthcare resources efficiently and to provide high quality medical care. The citizens of the southern European countries in general show lower satisfaction with healthcare service provision than the northern countries of the European Union. The average total expenditure in the health sector is $8,2 \%$ of the GDP of the EU Member States for the period 20002008. There are major differences between European countries in the terms of citizen health status. The search for increased efficiency implies the search for improved or stable quality service provision within given financial limits to achieve health and satisfaction among the population served. Many EU Member States recognise the inadequacy of their healthcare systems in the light of population ageing, sociodemographic developments and changing needs. The financial crisis has revealed major deficiencies in the area of healthcare system's financial regulation and supervision in developed countries, especially in United States.

The problems in the USA healthcare crisis started with the fact that the government spends more per person on healthcare than any other country, but according to World Health Organization the quality of healthcare in USA ranks 37th in the world. The US ranks only 13th among developed nations on the key leading healthcare indicator - average age expectancy - and lower if taking many less developed nations into consideration. The US spends more than 16 percent of its gross domestic product (GDP) on healthcare - a much greater share than other industrialized nations. The WHO analysis demonstrated that by 2017, healthcare expenditures are expected to consume nearly 20 percent of the USA GDP or $\$ 4.3$ trillion annually. The USA health costs are 50-60\% higher than those in Germany and France, and almost double those in Italy and the UK. The US healthcare system is very expensive and inefficient - it leaves 40 million citizens without coverage. Based on this obvious inefficiency is the suggestion of President Obama. He called for a comprehensive overhaul of the US healthcare system, warning that soaring medical costs present one of the greatest threats to the very foundation of the economy. According to President Obama in the time of the financial crisis the urgency of this task has become undeniable and the healthcare reform it is a fiscal imperative. In USA like in the other countries affected by the financial crisis, there is a fear recapitalizing banks and other financial institutions may be given priority.

Comparative studies show that in Europe and in US national interests are controversial with global ones, as governments transfer social responsibilities to market-driven agencies. These agencies are mostly transnational corporations, multinational insurance firms and big pharmaceutical companies, which use the global trade liberalization to maximize profits. The governments cannot completely and efficiently control the always-evolving dynamics of healthcare economics.

The healthcare reforms in Bulgaria started at the beginning of 1990s and were aimed to make the health system more efficient and relevant by improving quality of service and delivery of care, but after near twenty years of transition there are still many inefficiencies and problems. Until 2000 the healthcare system was financed mainly from general taxation from two main sources: the republican and municipal budgets respectively, but in addition, healthcare financing includes a private, outof-pocket component, a significant portion of which involves under-the-table payments. [3]

The system of health insurance is compulsory for the entire population, but in practice there are significant marginal social groups who are excluded from the system and they do not contribute to the National Health Insurance Fund (NHIF). At the same time the Constitution of the Republic of Bulgaria guarantees the right to healthcare to the entire population. This inequality is the main factor of the present underfinanced healthcare system. [4] As a result although the healthcare system has aimed to provide free comprehensive healthcare, the patients have paid out-ofpocket for many healthcare services.

Bulgaria still has one of the worst healthcare systems in Europe, according to the 2008 Euro Health Consumer Index (EHCI) report prepared by the Health Consumer Power House. We could find another negative assessment in the World Bank report (2008), where it is said that the healthcare reform in Bulgaria is "chaotic" and inefficient. Despite the wide reforms made before the accession to the European Union health sector in Bulgaria is still marked with endemic problems of corruption, low wages and staff shortages. The country places in 12th worst position in Europe in terms of disability-adjusted life years (DALYs) lost to all diseases and injuries in 2008. There are clear signs that the Bulgarian economy will soon be affected by the world financial crisis, since the country has a rather open economy, which makes it vulnerable to outside shocks. The govern- 
ment has revised its 2009 budget in order to be more cautious. The GDP growth forecast for 2009 was cut by almost a third to $4.7 \%$. According to this prognosis the accumulate problems of the healthcare system are expected to grow. There is strong imperative to accept measures that increase the effectiveness of spending for health. The perceived Bulgaria's 2009 budget for healthcare (about 400 million leva) could not cushion the financial slowdown. The high rate of unemployment could cause a decrease in the revenues in National Health Insurance Fund. If the global crisis prolongs, the most important challenge for the Bulgarian healthcare systems would be the limited financing, followed by large debts, lack of appropriate investment policy, informal payments and inefficient management. One of the approaches to cope with the expected crisis in the healthcare sector is the introduction of alternative private health insurance companies. The monopoly of the NHIF is proven ineffective, but there is lack of political will for deregulation. It is a well-known fact in economics that over-regulation stifles innovation, protects outdated practices, raises costs and decreases access to services. Unfortunately the aim of National Health Insurance Fund, to provide equitable access to health care, is a mirage rather than a reality, as the vast bulk of health care is self funded [5].

References:

1. The Financial Crisis and Global Health, World Health Organization report, Geneva, 2009

2. Healthcare systems in the EU - a comparative study, Public Health and Consumer Protection Series, 2008

3. Georgieva L, Salchev P, Dimitrova S, Dimova A, Avdeeva O. Bulgaria: Health system review. Health Systems in Transition, 2007; 9(1)

4. Koulaksazov, S. et al. in Tragakes, E. (ed.) Healthcare systems in transition: Bulgaria. Copenhagen, European Observatory on Healthcare Systems, 2003, 5(2),

\section{Conclusion}

In terms of healthcare system improvement the process of globalization has two sides. First, the innovations were spread worldwide and many people benefit from new medical methods. In the other hand, long before the current financial crisis the globalization causes growing social inequality and a crisis of massive global poverty. A growing number of people have no access to medical care even in the developed economies. In conclusion the process of globalization has brought many benefits but had become unbalanced, unfair, and unsustainable. Despite strong economic growth that produced millions of new jobs since the early 1990s, income inequalities grew dramatically in most regions of the world and is expected to increase due to the current global financial crisis. In USA the global financial crisis helps to clarify the need to find a way to reduce the growth in healthcare costs and it demonstrates the possibilities of the government to respond to financial and other economic crises. [6] Worldwide the ongoing global economic slowdown is affecting low-income groups disproportionately. The EU Member States, included Bulgaria, need to step up their efforts to improve value for money in the provision of healthcare and to reduce health inequalities, notably through increased attention to primary care, prevention, health promotion, better coordination and rational use of resources.
5. Short, S., Hadjiev, V. Toneva, Z. "On the inequitable impact of universal health insurance: The experience of Bulgaria in transition", Health Sociology Review, 2008, 16 (2)

6. Wendt, C., Frisina, L., Rothgang, H. "Healthcare System Types: A Conceptual Framework for Comparison", Social Policy and Administration, 2009, 43(1) 